\title{
Developing nations offer hope in climate talks
}

\section{MONTREAL}

Delegates from across the world returned home optimistic last weekend after climatechange talks in Montreal, Canada, despite the United States' continuing refusal to commit itself to reducing greenhouse gases.

A key outcome is an agreement by parties to the Kyoto Protocol to discuss deeper commitments to reducing greenhouse-gas emissions, as well as finding creative ways to engage developing countries. Some observers believe that the stage has now been set for long-term cooperation between developing and industrial nations within the treaty.

For instance, Papua New Guinea and several other countries said they want to hold discussions on how to create financial incentives to avoid deforestation in their countries. In addition, China has declared its intent to more than double its use of renewable energy, to $15 \%$ of its electrical demand, by 2020 . Some at the meeting believe this might lead to non-binding targets within the next commitment period of the Kyoto treaty. China could potentially receive carbon credits if it exceeds that goal.

"These are the kind of innovative things that we now have a negotiating space for countries to put on the table," says Alden Meyer, director of strategy and policy for the Union of Concerned Scientists in Washington DC.

More good news came as talks on the final day, 9 December, lasted into early Saturday morning. Just after midnight, the US delegation finally agreed to consider a dialogue on future strategies. The wording of the text is vague, but the agreement to continue at all was a "tactical
IMAGE

UNAVAILABLE FOR COPYRIGHT REASONS

China has targeted renewable energy as an alternative to its conventional power stations.

victory", says Maria Socorro Manguiat, a legal officer at the World Conservation Union.

The United States is not a party to the Kyoto protocol and so is under no obligation to discuss binding targets for emissions cuts. But a proposal made in the first week of talks by the conference president, Canada's environment minister Stéphane Dion, opened up the floor for future discussions under the United Nations Framework Convention on Climate Change, to which the United States is a party.

The Montreal talks ran on parallel tracks: one for countries that are parties to the convention, and one for countries that have ratified the Kyoto protocol. One of the problems with the protocol - particularly for countries such as Australia and the United States that have not ratified it - is that it mandates binding limits on greenhouse-gas emissions only for industrialized, not developing, nations.

By the end of the talks, parties to the Kyoto treaty had agreed to take part in negotiations towards deeper emissions cuts and other options for stabilizing emissions after 2012, when the Kyoto commitment period ends. They did not agree to a deadline for setting post-2012 commitments, but many observers think there is now a forum in which to engage developing countries such as China, India and Brazil in discussing how to reduce emissions while advancing economic development.

Throughout the conference, the United States insisted that one way forward was through bilateral and multilateral partnerships. One such initiative is the Asia-Pacific Partnership on Clean Development and Climate, which it set up in the summer with Australia and four other countries. This is set to kick off with a ministerial meeting in January. "The partnership will help speed the development of cleaner, more efficient energy systems in some of the world's fastest-growing economies," said Paula Dobriansky, head of the US delegation.

But critics say this is merely a political tool. "At this stage the partnership is simply a skeleton," says Christine Milne, vice-president of the World Conservation Union. The agreement currently has no emissions targets, timelines or funding. "The proof of the pudding will be at the ministerial meeting in Sydney in January," she says.

Amanda Haag

\section{Fake pottery buries theory of early start for Christianity}

\begin{abstract}
Artefacts recently unearthed in the Netherlands seemed to show that Christianity was openly practised there much earlier than previously thought. But now they have been shown to be fakes.
\end{abstract}

The archaeologists who dug up the pieces admitted their error last week in the 2005 yearbook of the historical association Numaga. The artefacts, including four pieces of pottery and glass, and a lead platter, were found at different sites in Nijmegen, the oldest city in the Netherlands, between 1995 and 1999. They were briefly displayed five years ago at Nijmegen's Valkhof Museum.

Most historians think that Christianity was first practised openly after AD 400. But the team of archaeologists, led by Harry van Enckevort, at first dated the items at about AD 200. Other archaeologists expressed doubts about the objects' authenticity at the time of the finds, but it was not until last year that van Enckevort decided to have the finds scientifically analysed.

The tests showed that the inscriptions on the glass and pottery shards were added in the 1990s, although the shards themselves were from around $A D 200$. The lead plate was a mere 20 years old.

"You don't expect objects to be fake when you find them embedded in the ground," says van Enckevort. Their appearance had convinced him that they were genuine.

The Dutch scandal is the latest of several recent archaeological scams. Earlier this year staff at the Israel Museum in Jerusalem had to remove from display one of its most prized pieces - an ivory pomegranate that bears an inscription hinting that it had been used by priests in Solomon's Temple - after finding out that it was fake (see Nature 434, 13; 2005). And in 2000 one of the most famous archaeologists in Japan, Fujimura Shinichi, was caught burying artefacts at an archaeological site.

Lothar Bakker, director of the Roman Museum in Augsburg, Germany, and an expert in Christian inscriptions on Roman objects, says that he "wouldn't have trusted the objects" because similar finds have always been later than AD 400 . Siëlle Gramser 